\title{
Analisis Kualitas Pelayanan Publik dengan Metode Fuzzy-Service Quality (F-Servqual) dan Index Potential Gain Customer Value (IPGCV)
}

\author{
Wahyu Oktri Widyarto*, Nugraheni Djamal, Fauzul Adhim \\ Program Studi Teknik Industri, Fakultas Teknik, Universitas Serang Raya, Jalan Raya Serang, Cilegon KM. 5 Taman \\ Drangong, Kota Serang, Banten 42116 Indonesia
}

\section{ARTICLE INFORMATION}

Article history:

Received: October 11, 2018

Revised: December 11,2018

Accepted: December 26, 2018

\section{Kata Kunci:}

Fuzzy-Servqual

Harapan

Index PGCV

Persepsi

\section{A B S T R A K}

Penelitian ini bertujuan untuk melakukan analisis tingkat kualitas pelayanan dan menentukan prioritas perbaikan. Metode yang digunakan adalah service quality (SERVQUAL) yang dikombinasikan dengan konsep fuzzy untuk mengetahui gap antara harapan dan persepsi konsumen melalui lima dimensi yaitu tangible, reliability, responsiveness, assurance dan empathy. Konsep fuzzy digunakan dalam mempresentasikan ketidakpastian atas penilaian responden terhadap kuisioner yang bersifat subyektif. Selanjutnya, untuk menentukan prioritas perbaikan, digunakan metode Index Potential Gains Customer Value (IPGCV). Berdasarkan hasil pengolahan data yang dilakukan dengan metode fuzzy-Servqual, diketahui bahwa dimensi Tangible memilik gap $-0,13$, dimensi Reliability memiliki gap $-0,13$, dimensi Responsiveness memiliki gap -0,14, dimensi Assurance memiliki gap -0,12, dimensi Empathy memiliki gap $-0,11$. Nilai negatif pada penilaian fuzzy-Servqual dapat diartikan bahwa pelayanan secara keseluruhan belum memenuhi harapan pelanggan. Capaian tingkat kualitas yaitu sebesar 0,8606 menunjukkan bahwa kualitas pelayanan yang selama ini diberikan memerlukan perbaikan, karena tingkat kualitas pelayanan kurang dari $1 \quad(Q<1)$. Berdasarkan pengolahan menggunakan Index PGCV, diketahui layanan yang mendapat prioritas utama adalah karyawan yang mendapat dukungan memadai dari institusinya sehingga dapat melaksanakan tugasnya dengan baik.

\section{A B S T R A C T}

This study aims to analyze the level of service quality and prioritize improvements. The method that used in this study is service quality (SERVQUAL) combined with fuzzy concepts to find out the gap between expectations and consumer perceptions through five dimensions namely tangible, reliability, responsiveness, assurance, and empathy. Fuzzy concepts are used to present uncertainties over respondents' assessment of subjective questionnaires. To determine the priority of improvement, used the Customer Value Index Potential Gains (IPGCV) method. Based on processing data results by using fuzzy-servqual method, it is known that the Tangible dimension has a gap of -0.13 , the Reliability dimension has a gap of -0.13 , the Responsive dimension has a gap of -0.14 , the dimension of Assurance has a gap of -0.12 , Empathy dimension has a gap of -0.11 . The negative value on fuzzy-servqual assessment can be interpreted that the overall service has not met customer expectations. Achievement of the quality level is equal to 0.8606 which is indicates the quality of services still need improvement because the level of service quality is less than $1(Q<1)$. Based on calculation using the PGCV Index, it is known that services which have the highest priority are employees who have adequate support from their institutions so that they can carry out their duties properly. 


\section{PENDAHULUAN}

Pelayanan publik sebagai salah satu fungsi pemerintah untuk memenuhi kebutuhan masyarakat. Masyarakat mulai kritis dalam menilai pelayanan dari instansi pemerintah dalam berbagi aspek transparansi, akuntabilitas, efisiensi dan efektifitas. Sebagai upaya mewujudkan good governance, sudah semestinya instansi pemerintah memberikan pelayanan sebaik-baiknya. Pelaksanaan pelayanan publik yang optimal mempunyai dampak positif terhadap kepuasan masyarakat terhadap instansi yang terkait [1].

Kualitas memiliki peranan penting dalam upaya meningkatkan, mempertahankan dan mendapatkan kembali pangsa pasar pada perusahaan bisnis baik perusahaan manufaktur maupun jasa [2]. Kualitas pelayanan yang diberikan kepada konsumen untuk menciptakan kepuasan konsumen merupakan kunci sukses untuk unggul dalam persaingan bisnis [3]. Oleh karena itu, diperlukan adanya pengukuran tingkat kualitas pelayanan untuk mengetahui kinerja pelayanan yang diberikan dengan menentukan kesenjangan antara harapan dengan perspesi konsumen terhadap suatu pelayanan yang diterimanya [4].

Penelitian mengenai pengukuran kualitas pelayanan telah banyak dilakukan oleh beberapa peneliti sebelumnya. Kualitas pelayanan di rumah sakit dengan menggunakan metode Fuzzy Servqual [5]-[7], hotel [8], telekomunikasi [9], bank [2] maupun bidang lainnya. Penggunaan metode servqual dan fuzzy dalam mengukur tingkat kepuasan konsumen terhadap pelayanan yang telah diberikan serta mengidentifikasi faktor pelayanan yang perlu dilakukan perbaikan [6]. IPGCV digunakan untuk memberikan urutan prioritas perbaikan kualitas pelayanan [10]-[12].

Pengukuran kualitas pelayanan dapat dilakukan dengan beberapa metode, salah satunya adalah metode Service Quality (SERVQUAL). Penelitian ini menggunakan metode SERVQUAL yang dikombinasikan dengan metode fuzzy untuk mengetahui kesenjangan/gap antara harapan dengan persepsi konsumen yang menunjukkan kualitas pelayanan melalui lima dimensi pengukuran kualitas dari SERVQUAL yaitu tangible, reliability, responsiveness, assurance dan empathy. Metode Index Potential Gains Customer Value (IPGCV) dapat digunakan untuk menentukan urutan pioritas perbaikan atribut.

Kualitas pelayanan merupakan faktor penting bagi penyedia layanan dalam mencapai kualitas yang diterima sesuai dengan pelayanan yang diharapkan konsumen [13]-[15]. Kesenjangan antara harapan dengan persepsi konsumen ini perlu dicari solusinya untuk mengurangi dan/atau menghilangkan kesenjangan tersebut [16]. Harapan konsumen adalah ekspektasi pelayanan berdasarkan kebutuhan kosumen yang hasilnya dapat kurang atau lebih dari kenyataan [8]. Sedangkan persepsi konsumen adalah cara pandang konsumen dalam menilai suatu pelayanan yang diberikan yang dapat diukur dari kesesuaian atau tidak.

Konsep fuzzy dapat digunakan dalam menghubungkan ketidakpastian atas penilaian responden pada kuisioner yang bersifat subyektif menjadi lebih objektif. Penentuan prioritas rencana perbaikan juga diperlukan untuk meningkatkan kualitas pelayanan. Dasar logika fuzzy adalah teori himpunan fuzzy dengan derajat keanggotaan sebagai penentu keberadaan elemen suatu himpunan. Nilai keanggotaan atau derajat keanggotaan atau membership function menjadi ciri utama dari penalaran dari logika fuzzy tersebut. Pada himpunan fuzzy nilai keanggotaan terletak pada rentang 0 sampai dengan 1 [17].

Berdasarkan uraian tersebut, maka akan dilakukan pengukuran mengenai kualitas pada salah satu pelayanan publik menggunakan metode Fuzzy-Service Quality (F-Servqual) dengan menentukan nilai gap antara harapan dengan persepsi konsumen dari setiap dimensi kualitas, menentukan nilai kualitas pelayanandan menentukan prioritas rencana perbaikan kualitas pelayanan dengan metode Index Potential Gain Customer Value (IPGCV).

\section{METODE PENELITIAN}

Penelitian ini dilakukan pada pelayanan pajak kendaraan bermotor pribadi dengan menggunakan kuesioner sebagai instrumen penelitian. Responden yang dipilih pada penelitian ini adalah pemilik kendaraan beromotor roda dua dan roda empat. Teknik penentuan sampel yaitu dengan menggunakan teknik Slovin.

\section{Servqual}

Parasuraman [18] menggunakan sepuluh dimensi layanan sebagai dasar untuk mengembangkan 97 pertanyaan dengan mengadopsi konsep kualitas layanan yang berasal dari perbedaan antara layanan yang diharapkan pelanggan dan layanan diterima. Skala ini 
dibentuk menggunakan lima dimensi dan 22 pertanyaan kualitas layanan. Skala ini disebut "SERVQUAL", dan lima dimensi skala masingmasing adalah Tangibles, Reliability, Responsiveness, Assurance dan Empathy [19].

1. Tangible, adalah dimensi yang berhubungan dengan penampilan fisik sepertidesign (warna, perabotan, dan tata letak keseluruhan area), sosial (karyawan, pelanggan, dan nonpelanggan) dan tampilan (aroma, suhu, cahaya, dII) [20].

2. Reliability, adalah kemampuan memberikan pelayanan yang handal sesuai dengan yang telah dijanjikan.

3. Responsiveness, adalah kesigapan pelayanan dalam memberikan pelayanan yang baik dan cepat.

4. Assurance, adalah kemampuan pelayanan dalam memberikan informasi,keramahan, kesopanan, dan perhatian dalam melayani pelanggan.

5. Empathy,adalah perhatian yang diberikan petugas pelayanan konsumen seperti halnya kemudahan akses, informasi mengenai harga, fasilitas, dan lainnya.

Faktor kualitas semestinya harus dipertimbangkan oleh perusahaan bisnis baik manufaktur maupun jasa dalam menghadapi persaingan untuk bertahan maupun menambah pangsa pasar [2]. Untuk mencari kesenjangan kualitas pelayanan, dapat digunakan formula sebagai berikut [5]:

Gap $=$ Persepsi - Harapan

Servqual tidak hanya dapat digunakan untuk mencari kesenjangan harapan dan persepsi konsumen tapi juga dapat digunakan untuk mencari tingkat kualitas pelayanan [21] dengan menggunakan formula:

Kualitas $(Q)=\frac{\text { Penilaian }}{\text { Harapan }}$

Jika $Q \geq 1$, maka kualitas pelayanan dikatakan baik.

Jika $Q<1$ maka kualitas pelayanan dikatakan kurang baik.

\section{Fuzzy}

Konsep fuzzy juga mengenal himpunan level-a atau a - cut yang merupakan himpunan crispdengan elemen-elemen himpunan fuzzy $\tilde{A}$ dengan derajat keanggotaan sekurangkurangnya a, yang ditulis dengan $\tilde{A} \alpha=\{(x \in X \mid$ $\left.\mu_{\tilde{A}}(x)>\alpha\right\}, \alpha \in[0,1]$. Proses fuzzyfikasi adalah proses memproses nilai crisp ke dalam bahasa fuzzy yang dilakukan dengan menggunakan Overall Effectiveness Measure (OEM) [10].

$O E M_{i}=\left(\frac{1}{N}\right) \times\left[\left(P M_{i}^{j} \times P I^{1}\right)+\left(P M_{i}^{j} \times P I^{2}\right)+\ldots+\left(P M_{i}^{j} \times P I^{N}\right)\right]$

Keterangan:

$P M_{i}^{j} \quad$ : Bobot nilai fuzzy indikator ke I variabel ke j

$\mathrm{PI}^{\mathrm{N}} \quad$ : Tingkat kepentingan relatif

I : Kriteria $(1,2,3, \ldots \ldots \ldots . . . m)$

j $\quad$ : Linguistik variabel $(1,2,3, \ldots \ldots . . k)$

$\mathrm{N}$ : Banyaknya indikator

M : Banyaknya variabel

Deffuzyfikasi merupakan transformasi yang menyatakan kembali output dari domain fuzzy kedalam domain crisp dengan menggunakan rumus geometric mean [10]:

$$
\text { Defuzzyfikasi }=\left(a_{i}+b_{i}+c_{i}\right)^{1 / 3}
$$

Keterangan :

$a_{\mathrm{i}} \quad$ : batas bawah

$b_{\mathrm{i}} \quad$ : batas tengah (crisp)

$c_{\mathrm{i}} \quad$ : batas atas

\section{Index Potential Gain Customer Value}

Potential Gain in Customer Value (PGCV) adalah metode penentuan prioritas perbaikan berdasarkan suara [22]. Dengan PGCV maka akan diketahui urutan prioritas perbaikan atribut.

Langkah-langkah dalam penentuan indeks PGCV yaitu [16] :

1. Menghitung nilai Achieved Customer Value (ACV)

$$
\mathrm{ACV}=\mathrm{I} \times \mathrm{P}
$$

ACV : Nilai pencapaian konsumen

I : Nilai rata-rata untuk ekspektasi

$\mathrm{P} \quad$ : Nilai rata-rata untuk kinerja 
2. Menghitung Ultimate Desired Customer Value (UDCV)

$\mathrm{UDCV}=\mathrm{I} \times \operatorname{Ps}(5)$

UDCV : Nilai akhir keinginan konsumen

I : Nilai rata-rata untuk ekspektasi

Ps : Nilai kinerja maksimum dalam skala likert yang dipilih.

3. Indeks PGCV

$P G C V=$ UDCV $-A C V$

\section{HASIL DAN PEMBAHASAN}

Instrumen yang digunakan pada penelitian ini yaitu kuesioner yang disebarkan pada 100 responden. Penentuan jumlah sampel responden dengan menggunakan formula Slovin [23].

$$
\begin{aligned}
& n=\frac{N}{1+N \cdot e^{2}} \\
& n=\frac{271128}{1+271128(0,1)^{2}} \\
& n=99,97=100 \\
& \text { Di mana: }
\end{aligned}
$$

\begin{tabular}{|c|c|c|}
\hline Dimensi & Atribut & Referensi \\
\hline \multirow{3}{*}{ Tangible } & Peralatan dan teknologi mutakhir & {$[3],[5],[8],[10]$} \\
\hline & Fasilitas fisik & {$[3],[5],[6],[8],[10],[24],[25]$} \\
\hline & Penampilan karyawan & [3], [6], [8], [10], [25] \\
\hline \multirow{5}{*}{$\begin{array}{l}\text { Keandalan } \\
\text { (Reliability) }\end{array}$} & Kesesuaian pelayanan yang dijanjikan & [1], [3], [5], [8], [24], [26] \\
\hline & $\begin{array}{l}\text { Kemampuan karyawan dalam } \\
\text { menyelesaikan masalah }\end{array}$ & [1], [3], [24] \\
\hline & Karyawan dapat diandalkan/dipercaya & [1], [3], [8], [24], [25] \\
\hline & Pelayanan secara tepat waktu & {$[3],[5],[6],[24],[26]$} \\
\hline & Karyawan bekerja secara akurat & {$[3],[5],[6],[8],[10],[24]-[26]$} \\
\hline \multirow{4}{*}{$\begin{array}{l}\text { Daya Tanggap } \\
\text { (Responsiveness) }\end{array}$} & Memberitahukan waktu pemberian jasa & {$[3],[6],[24]$} \\
\hline & Kecepatan jasa pelayanan & {$[1],[3],[6],[10],[24],[26]$} \\
\hline & Karyawan selalu bersedia membantu & {$[3],[6],[10],[24],[25]$} \\
\hline & $\begin{array}{l}\text { Respon terhadap setiap permintaan } \\
\text { pelayanan dengan cepat. }\end{array}$ & {$[10],[24]$} \\
\hline \multirow{4}{*}{$\begin{array}{l}\text { Jaminan } \\
\text { (Assurance) }\end{array}$} & Kepercayaan terhadap karyawan. & [3], [5] \\
\hline & $\begin{array}{l}\text { Perasaan aman bertransaksi dalam sistem } \\
\text { pelayanan perusahaan. }\end{array}$ & {$[3],[5],[10],[24],[25]$} \\
\hline & Karyawan bersikap sopan & [3], [6], [24], [25] \\
\hline & $\begin{array}{l}\text { Karyawan mendapat dukungan memadai } \\
\text { dari institusinya sehingga dapat } \\
\text { melaksanakan tugasnya dengan baik. }\end{array}$ & [3], [8], [10] \\
\hline \multirow{5}{*}{$\begin{array}{l}\text { Empati } \\
\text { (Empathy) }\end{array}$} & Kemudahan akses profil perusahaan & [1], [10] \\
\hline & \multirow{2}{*}{$\begin{array}{l}\text { Kenyamanan dan kebersihan perusahaan } \\
\text { Karyawan memahami jasa pelayanan yang } \\
\text { dibutuhkan. }\end{array}$} & [1], [8] \\
\hline & & {$[1],[3],[5],[8]$} \\
\hline & \multirow{2}{*}{$\begin{array}{l}\text { Perusahaan mempunyai fasilitas yang baik } \\
\text { Perusahaan memiliki waktu beroperasi } \\
\text { yang sesuai/cocok }\end{array}$} & [5], [8], [24] \\
\hline & & {$[5],[24]$} \\
\hline
\end{tabular}

Tabel 1. Desain Kuesioner 
Tabel 2. Uji Validitas

\begin{tabular}{|c|c|c|c|c|c|}
\hline & \multirow{2}{*}{ Pernyataan } & \multicolumn{2}{|c|}{ Nilai Korelasi } & \multirow{2}{*}{$\mathrm{r}_{\text {Tabel }}$} & \multirow{2}{*}{ Keterangan } \\
\hline & & Persepsi & Harapan & & \\
\hline \multirow{4}{*}{$\begin{array}{l}\text { Bukti Fisik } \\
\text { (Tangible/T) }\end{array}$} & $\begin{array}{l}\text { Perusahaan memiliki peralatan dan } \\
\text { teknologi terbaru (Mutakhir). (T1) }\end{array}$ & 0,673 & 0,683 & 0,1654 & Valid \\
\hline & Fasilitas fisik yang menarik. (T2) & 0,793 & 0,797 & 0,1654 & Valid \\
\hline & $\begin{array}{l}\text { Karyawan berpakaian dan } \\
\text { berpenampilan rapi.(T3). }\end{array}$ & 0,642 & 0,717 & 0,1654 & Valid \\
\hline & $\begin{array}{l}\text { Penampilan fasilitas fisik sesuai } \\
\text { dengan jenis jasa yang disediakan. } \\
\text { (T4) }\end{array}$ & 0,695 & 0,772 & 0,1654 & Valid \\
\hline \multirow{5}{*}{$\begin{array}{l}\text { Keandalan } \\
\text { (Reliability/R) }\end{array}$} & $\begin{array}{l}\text { Sewaktu berjanji untuk melakukan } \\
\text { sesuatu pada waktu yang disepakati } \\
\text { mereka menepatinya. (R1) }\end{array}$ & 0,762 & 0,744 & 0,1654 & Valid \\
\hline & $\begin{array}{l}\text { Sewaktu anda mendapat masalah, } \\
\text { karyawan bersikap simpatik dan } \\
\text { sanggup menenangkan anda. (R2). }\end{array}$ & 0,630 & 0,718 & 0,1654 & Valid \\
\hline & $\begin{array}{l}\text { Karyawan dapat } \\
\text { diandalkan/dipercaya. (R3). }\end{array}$ & 0,734 & 0,831 & 0,1654 & Valid \\
\hline & $\begin{array}{l}\text { Karyawan menyampaikan jasanya } \\
\text { sesuai dengan waktu yang } \\
\text { dijanjikan.(R4) }\end{array}$ & 0,737 & 0,854 & 0,1654 & Valid \\
\hline & Karyawan bekerja secara akurat.(R5) & 0,653 & 0,717 & 0,1654 & Valid \\
\hline \multirow{4}{*}{$\begin{array}{l}\text { Daya tanggap } \\
\text { (Responsiveness/RV) }\end{array}$} & $\begin{array}{l}\text { Karyawan memberitahu anda kapan } \\
\text { pastinya jasa akan disampaikan. } \\
\text { (RV1) }\end{array}$ & 0,602 & 0,742 & 0,1654 & Valid \\
\hline & $\begin{array}{l}\text { Anda menerima jasa yang } \\
\text { segera/cepat dari karyawan.(RV2) }\end{array}$ & 0,741 & 0,775 & 0,1654 & Valid \\
\hline & $\begin{array}{l}\text { Karyawan selalu bersedia membantu } \\
\text { anda. (RV3) }\end{array}$ & 0,613 & 0,822 & 0,1654 & Valid \\
\hline & $\begin{array}{l}\text { Karyawan sanggup menanggapi } \\
\text { setiap permintaan anda dengan } \\
\text { cepat. (RV4) }\end{array}$ & 0,722 & 0,758 & 0,1654 & Valid \\
\hline \multirow{4}{*}{$\begin{array}{l}\text { Jaminan } \\
\text { (Assurance/A) }\end{array}$} & Anda mempercayai karyawan. (A1) & 0,556 & 0,724 & 0,1654 & Valid \\
\hline & $\begin{array}{l}\text { Anda merasa aman bertransaksi } \\
\text { dalam sistem pelayanan } \\
\text { perusahaan.(A2) }\end{array}$ & 0,658 & 0,779 & 0,1654 & Valid \\
\hline & $\begin{array}{l}\text { Karyawan bersikap sopan pada } \\
\text { anda.(A3) }\end{array}$ & 0,652 & 0,745 & 0,1654 & Valid \\
\hline & $\begin{array}{l}\text { Karyawan mendapat dukungan } \\
\text { memadai dari institusinya sehingga } \\
\text { dapat melaksanakan tugasnya } \\
\text { dengan baik. (A4) }\end{array}$ & 0,613 & 0,627 & 0,1654 & Valid \\
\hline \multirow{5}{*}{$\begin{array}{l}\text { Empati } \\
\text { (Empathy/E) }\end{array}$} & $\begin{array}{l}\text { Profil mengenai perusahaan mudah } \\
\text { diakses.(E1) }\end{array}$ & 0,664 & 0,698 & 0,1654 & Valid \\
\hline & $\begin{array}{l}\text { Perusahaan mempunyai tempat yang } \\
\text { aman dan bersih. (E2) }\end{array}$ & 0,684 & 0,715 & 0,1654 & Valid \\
\hline & $\begin{array}{l}\text { Karyawan memahami kebutuhan } \\
\text { anda.(E3) }\end{array}$ & 0,774 & 0,777 & 0,1654 & Valid \\
\hline & $\begin{array}{l}\text { Perusahaan mempunyai fasilitas } \\
\text { yang baik bagi anda. (E4) }\end{array}$ & 0,677 & 0,799 & 0,1654 & Valid \\
\hline & $\begin{array}{l}\text { Perusahaan memiliki waktu } \\
\text { beroperasi yang sesuai/cocok bagi } \\
\text { anda. (E5) }\end{array}$ & 0,726 & 0,794 & 0,1654 & Valid \\
\hline
\end{tabular}




\section{Uji Validitas}

Pengujian validitas menggunakan korelasi dengan kententuan kuesioner dikatakan valid jika nilai $r_{\text {hitung }}>r_{\text {tabel. }}$. Dengan jumlah sampel $(n)=100$, maka dapat diketahui degree of freedom (df) sebesar 98 sehingga $r_{\text {tabel }}$ sebesar 0,1654 .

Berdasarkan tabel hasil uji validitas dapat diketahui bahwa semua item pernyataan dinyatakan valid karena seluruh item pertanyaan pada kuesioner menghasilkan nilai $r_{\text {hitung }}>r_{\text {tabel }}$ $(0,1654)$. Secara lengkap, hasil uji validasi kuisioner ditampilkan pada tabel 2 .

\section{Uji Reliabilitas}

Setelah dilakukan uji validasi, selanjutnya dilakukan uji reliabilitas untuk mengetahui sejauh mana kuesioner yang telah disebarkan dapat diandalkan dan dapat memberikan hasil pengukuran yang relatif konsisten dari waktu ke waktu.Kuesioner dikatakan reliabel jika nilai cronbach's alpha $(\alpha)$ suatu variabel $\geq 0,70$. [16]. Hasil uji reliabilitas pada Tabel 3 menunjukkan bahwa indikator yang digunakan telah reliable atau handal sehingga dapat digunakan sebagai alat ukur variabel karena semua variabel memiliki nilai diatas 0,70 .

Tabel 3. Uji Reliabilitas

\begin{tabular}{|c|c|c|c|}
\hline \multirow{2}{*}{ Dimensi } & \multicolumn{2}{|c|}{ Cronbach's Alpha } & \multirow{2}{*}{ Keterangan } \\
\hline & Persepsi & Harapan & \\
\hline Tangible & $0,776>0,70$ & $0,796>0,70$ & Reliabel \\
\hline Reliability & $0,778>0,70$ & $0,800>0,70$ & Reliabel \\
\hline Responsiveness & $0,763>0,70$ & $0,807>0,70$ & Reliabel \\
\hline $\begin{array}{l}\text { Assurance } \\
\text { Empathy }\end{array}$ & $\begin{array}{l}0,779>0,70 \\
0,779>0,70\end{array}$ & $\begin{array}{l}0,786>0,70 \\
0,795>0,70\end{array}$ & $\begin{array}{l}\text { Reliabel } \\
\text { Reliabel }\end{array}$ \\
\hline
\end{tabular}

\section{Penentuan Fuzzy Set}

Setiap kriteria yang diajukan dalam kuesioner, perlu ditentukan fuzzy set untuk mendapatkan skor yang harus diberikan oleh responden. Adapun defenisi dari variabel linguistik dan taksiran linguistik (aj, bj, cj) yang digunakan untuk persepsi dan ekspektasi adalah sebagai berikut:

$\begin{array}{ll}\text { STS } & \text { : Sangat Tidak Setuju }(0 ; 0 ; 0,25) \\ \text { TS } & \text { : Tidak Setuju }(0 ; 0,25 ; 0,5) \\ \text { N } & \text { : Netral }(0,25 ; 0,5 ; 0,75) \\ \text { S } & \text { : Setuju }(0,5 ; 0,75 ; 1) \\ \text { SS } & \text {; Sangat Setuju }(0,75 ; 1 ; 1) \\ \text { STD } & \text {; Sangat Tidak Diharapkan }(0 ; 0 ; 0,25) \\ \text { N } & \text {; Netral }(0,25 ; 0,5 ; 0,75) \\ \text { D } & \text {; Diharapkan }(0,5 ; 0,75 ; 1) \\ \text { SD } & \text { : Sangat Diharapkan }(0,75 ; 1 ; 1)\end{array}$

\section{Fuzzyfikasi}

Berikut ini adalah hasil perhitungan fuzzyfikasi menggunakan metode OEM (Overall Effectiveness Measure) (Tabel 4 dan 5).

Tabel 4. Fuzzyfikasi Persepsi Pelanggan

\begin{tabular}{|c|c|c|c|c|}
\hline No & Kode Atribut & & OEM & \\
\hline 1 & T1 & 0.41 & 065 & 087 \\
\hline 2 & T2 & 0,46 & 0,70 & 0,91 \\
\hline 3 & T3 & 0,53 & 0,78 & 0,95 \\
\hline 4 & $\mathrm{~T} 4$ & 0,49 & 0,73 & 0,94 \\
\hline 5 & R1 & 0,46 & 0,70 & 0,90 \\
\hline 6 & R2 & 0,44 & 0,68 & 0,88 \\
\hline 7 & R3 & 0,51 & 0,76 & 0,94 \\
\hline 8 & R4 & 0,48 & 0,73 & 0,93 \\
\hline 9 & R5 & 0,47 & 0,72 & 0,93 \\
\hline 10 & $\mathrm{RV} 1$ & 0,41 & 0,66 & 0,89 \\
\hline 11 & RV2 & 0,47 & 0,72 & 0,93 \\
\hline 12 & $\mathrm{RV} 3$ & 0,48 & 0,73 & 0,94 \\
\hline 13 & RV4 & 0,39 & 0,71 & 0,91 \\
\hline 14 & A1 & 0,39 & 0,70 & 0,91 \\
\hline 15 & A2 & 0,49 & 0,73 & 0,93 \\
\hline 16 & A3 & 0,52 & 0,77 & 0,95 \\
\hline 17 & A4 & 0,48 & 0,73 & 0,93 \\
\hline 18 & E1 & 0,44 & 0,69 & 0,90 \\
\hline 19 & E2 & 0,53 & 0,78 & 0,96 \\
\hline 20 & E3 & 0,46 & 0,71 & 0,92 \\
\hline 21 & E4 & 0,50 & 0,75 & 0,95 \\
\hline 22 & E5 & 0,50 & 0,75 & 0,94 \\
\hline
\end{tabular}


Tabel 5. Fuzzyfikasi Harapan Pelanggan

\begin{tabular}{rcrrr}
\hline No & Kode Atribut & A & $\begin{array}{c}\text { OEM } \\
\text { B }\end{array}$ & C \\
\hline 1 & T1 & 0,64 & 0,89 & 0,98 \\
2 & T2 & 0,62 & 0,87 & 0,97 \\
3 & T3 & 0,64 & 0,89 & 0,98 \\
4 & T4 & 0,61 & 0,86 & 0,97 \\
5 & R1 & 0,64 & 0,89 & 0,97 \\
6 & R2 & 0,63 & 0,88 & 0,97 \\
7 & R3 & 0,64 & 0,89 & 0,97 \\
8 & R4 & 0,64 & 0,89 & 0,97 \\
9 & R5 & 0,64 & 0,89 & 0,98 \\
10 & RV1 & 0,62 & 0,87 & 0,98 \\
11 & RV2 & 0,63 & 0,87 & 0,97 \\
12 & RV3 & 0,64 & 0,89 & 0,98 \\
13 & RV4 & 0,62 & 0,87 & 0,97 \\
14 & A1 & 0,61 & 0,86 & 0,97 \\
15 & A2 & 0,62 & 0,87 & 0,97 \\
16 & A3 & 0,65 & 0,90 & 0,98 \\
17 & A4 & 0,62 & 0,87 & 0,98 \\
18 & E1 & 0,62 & 0,87 & 0,97 \\
19 & E2 & 0,66 & 0,91 & 0,98 \\
20 & E3 & 0,61 & 0,86 & 0,97 \\
21 & E4 & 0,65 & 0,90 & 0,97 \\
22 & E5 & 0,64 & 0,89 & 0,98 \\
\hline & & & & \\
1 & & &
\end{tabular}

\section{Defuzzyfikasi}

Setelah melakukan perhitungan fuzzyfikasi, selanjutnya dilakukan defuzzyfikasi menggunakan metode Arithmatic Mean (Tabel 6). Setelah melakukan defuzzyfikasi per kriteria, selanjutnya dilanjutkan perhitungan selisih antar gap, sejauh mana selisih persepsi dan ekspektasi per dimensi. Tabel 7 menunjukkan hasil analisis gap antar dimensiServqual.

Untuk menganalisis kualitas pelayanan yang telah diberikan, maka dilakukan analisis tingkat kualitas pelayanan. Hasil analisis tingkat kualitas pelayanan ditampilkan pada tabel 8. Dari perhitungan analisis kualitas pelayanan, menunjukkan bahwa semua dimensi kualitas pelayanan yang meliputi Bukti Fisik (tangible), Reliabilitas (reliability), Daya Tanggap (responsive), Jaminan (assurance) dan Empati (empathy) mempunyai nilai dibawah 1, yang dapat diinterpretasikan bahwa kualitas dari setiap dimensi pelayanan bisa dikatakan masih perlu perhatian perbaikan dan memiliki nilai rata-rata dari semua dimensi sebesar 0.84
Tabel 6. Defuzzyfikasi

\begin{tabular}{|c|c|c|c|c|}
\hline \multirow[b]{2}{*}{ Dimensi } & \multirow[b]{2}{*}{ Kode Atribut } & \multicolumn{2}{|c|}{ Defuzzyfikasi } & \multirow[b]{2}{*}{ Gap } \\
\hline & & Persepsi & Harapan & \\
\hline \multirow{4}{*}{ 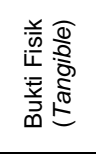 } & T1 & 0,64 & 0,84 & $-0,20$ \\
\hline & T2 & 0,69 & 0,82 & $-0,13$ \\
\hline & T3 & 0,75 & 0,84 & $-0,08$ \\
\hline & T4 & 0,72 & 0,81 & $-0,09$ \\
\hline \multirow{5}{*}{ 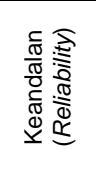 } & R1 & 0,69 & 0,83 & $-0,15$ \\
\hline & $\mathrm{R} 2$ & 0,67 & 0,83 & $-0,16$ \\
\hline & R3 & 0,74 & 0,83 & $-0,10$ \\
\hline & $\mathrm{R} 4$ & 0,71 & 0,83 & $-0,12$ \\
\hline & R5 & 0,71 & 0,84 & $-0,13$ \\
\hline \multirow{4}{*}{ 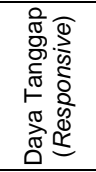 } & RV1 & 0,65 & 0,82 & $-0,17$ \\
\hline & RV2 & 0,71 & 0,82 & $-0,12$ \\
\hline & RV3 & 0,72 & 0,84 & $-0,12$ \\
\hline & RV4 & 0,67 & 0,82 & $-0,15$ \\
\hline \multirow{4}{*}{ 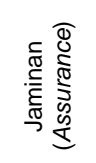 } & $\mathrm{A} 1$ & 0,67 & 0,81 & $-0,15$ \\
\hline & $\mathrm{A} 2$ & 0,72 & 0,82 & $-0,10$ \\
\hline & A3 & 0,75 & 0,84 & $-0,10$ \\
\hline & A4 & 0,71 & 0,82 & $-0,11$ \\
\hline \multirow{5}{*}{ 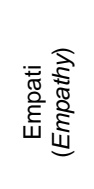 } & E1 & 0,68 & 0,82 & $-0,14$ \\
\hline & E2 & 0,76 & 0,85 & $-0,09$ \\
\hline & E3 & 0,70 & 0,81 & $-0,12$ \\
\hline & E4 & 0,73 & 0,84 & $-0,11$ \\
\hline & E5 & 0,73 & 0,84 & $-0,11$ \\
\hline
\end{tabular}

Tabel 7. Gap Deffuzzyfikasiantar Dimensi Kualitas Pelayanan

\begin{tabular}{llll}
\hline Dimensi & Persepsi & Ekspektasi & Gap \\
\hline Tangible & 0,70 & 0,83 & $-0,13$ \\
Reliability & 0,70 & 0,83 & $-0,13$ \\
Responsive & 0,69 & 0,83 & $-0,14$ \\
Assurance & 0,71 & 0,83 & $-0,12$ \\
Empathy & 0,72 & 0,83 & $-0,11$ \\
\hline Rata-rata & 0,704 & 0,83 & $-0,12$ \\
\hline
\end{tabular}

Tabel 8. Kualitas Pelayanan

\begin{tabular}{llll}
\hline Dimensi & $\begin{array}{l}\text { Skor } \\
\text { Penilaian } \\
\text { Persepsi } \\
(\mathrm{P})\end{array}$ & $\begin{array}{l}\text { Skor } \\
\text { Penilaian } \\
\text { Harapan } \\
(\mathrm{E})\end{array}$ & $\mathrm{Q}=\mathrm{P} / \mathrm{E}$ \\
\hline Tangible & 0,7 & 0,83 & 0,84 \\
Reliability & 0,7 & 0,83 & 0,84 \\
Responsive & 0,69 & 0,83 & 0,83 \\
Assurance & 0,71 & 0,82 & 0,87 \\
Empathy & 0,72 & 0,83 & 0,87 \\
\hline Rata - Rata & 0,70 & 0,83 & 0,84 \\
\hline
\end{tabular}


Index PGCV

Indeks PGVC digunakan untuk menentukan prioritas rencana tindakan perbaikan kualitas pelayanan. Tabel 9 menunjukkan hasil perhitungan indeks PGCV.

Tabel 9. Perhitungan Indeks PGCV

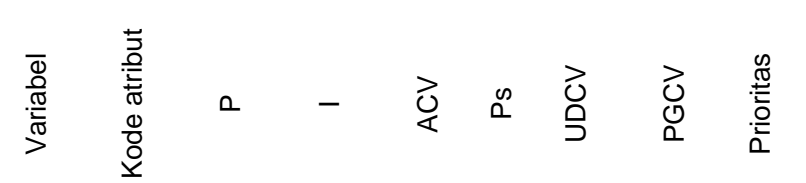

\begin{tabular}{lllllllll}
\hline 1 & $\mathrm{~T} 1$ & 3,15 & 3,67 & 11,6 & 5 & 18,3 & 6,77 & 3
\end{tabular}

$\begin{array}{lllllllll}1 & \text { T1 } & 3,15 & 3,67 & 11,6 & 5 & 18,3 & 6,77 & 3 \\ 2 & \text { T2 } & 3,42 & 3,67 & 12,5 & 5 & 18,3 & 5,79 & 7 \\ 3 & \text { T3 } & 3,67 & 3,67 & 13,4 & 5 & 18,3 & 4,90 & 18\end{array}$

$$
\begin{array}{llllllllll} 
& \text { T4 } & 3,67 & 3,42 & 12,5 & 5 & 17,1 & 4,57 & 20
\end{array}
$$$$
\begin{array}{lllllllll}
5 & \text { R1 } & 3,67 & 3,67 & 13,4 & 5 & 18,3 & 4,90 & 14
\end{array}
$$$$
\begin{array}{lllllllll}
6 & \text { R2 } & 3,67 & 3,42 & 12,5 & 5 & 17,1 & 4,57 & 19
\end{array}
$$$$
\begin{array}{lllllllll}
6 & \mathrm{R} 2 & 3,67 & 3,42 & 12,5 & 5 & 17,1 & 4,57 & 19
\end{array}
$$

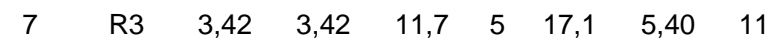$$
8 \quad \mathrm{R} 4 \quad 3,15 \quad 3,27 \quad 10,3 \quad 5 \quad 16,3 \quad 6,03 \quad 5
$$$$
\begin{array}{lllllllll}
9 & \mathrm{R} 5 & 3,63 & 3,67 & 13,3 & 5 & 18,3 & 5,03 & 12
\end{array}
$$$$
10 \quad \mathrm{RV} 1 \quad 3,67 \quad 3,67 \quad 13,4 \quad 5 \quad 18,3 \quad 4,90 \quad 13
$$$$
11 \quad \text { RV2 } 3,67 \quad 3,67 \quad 13,4 \quad 5 \quad 18,3 \quad 4,90 \quad 15
$$$$
12 \begin{array}{llllllll}
\mathrm{RV} 3 & 3,67 & 3,67 & 13,4 & 5 & 18,3 & 4,90 & 16
\end{array}
$$

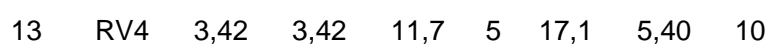$$
14 \quad \mathrm{~A} 1 \quad 3,27 \quad 3,42 \quad 11,1 \quad 5 \quad 17,1 \quad 5,93 \quad 6
$$$$
\begin{array}{lllllllll}
15 & \text { A2 } & 3,42 & 3,67 & 12,5 & 5 & 18,3 & 5,79 & 8
\end{array}
$$$$
\begin{array}{lllllllll}
16 & \text { A3 } & 3,67 & 2,86 & 10,5 & 5 & 14,3 & 3,82 & 22
\end{array}
$$$$
\begin{array}{lllllllll}
17 & \text { A4 } & 2,25 & 2,86 & 6,4 & 5 & 14,3 & 7,87 & 1
\end{array}
$$$$
\begin{array}{lllllllll}
18 & \text { E1 } & 3,27 & 3,67 & 12,0 & 5 & 18,3 & 6,35 & 4
\end{array}
$$$$
19 \quad \text { E2 } \quad 2,55 \quad 3,06 \quad 7,8 \quad 5 \quad 15,3 \quad 7,50 \quad 2
$$$$
20 \quad \text { E3 } \quad 3,42 \quad 2,67 \quad 9,1 \quad 5 \quad 13,3 \quad 4,21 \quad 21
$$$$
\begin{array}{lllllllll}
21 & \text { E4 } & 3,67 & 3,67 & 13,4 & 5 & 18,3 & 4,90 & 17
\end{array}
$$$$
\begin{array}{lllllllll}
21 & \text { E4 } & 3,67 & 3,67 & 13,4 & 5 & 18,3 & 4,90 & 17 \\
22 & \text { E5 } & 3,06 & 2,92 & 8,9 & 5 & 14,6 & 5,65 & 9
\end{array}
$$

\begin{tabular}{lccc}
\multicolumn{3}{c}{ IPGCV } \\
\hline Prioritas & PGCV & Variabel & Kode Atribut \\
\hline 1 & 7,865 & 17 & A4 \\
2 & 7.429 & 19 & E2 \\
3 & 6.766 & 1 & T1 \\
4 & 6.348 & 18 & E1 \\
5 & 6.033 & 8 & R4 \\
\hline
\end{tabular}

Adapun data rekapitulasi analisis GAP dan IPGCV ditampilkan pada tabel 10.

Tabel 10. Rekapitulasi Analisis GAP dan Indeks PGCV

\begin{tabular}{cccc}
\hline Variabel & Kode Atribut & GAP & PGCV \\
\hline 1 & T1 & $-0,20$ & 6,766 \\
2 & T2 & $-0,13$ & 5,787 \\
3 & T3 & $-0,08$ & 4,893 \\
4 & T4 & $-0,09$ & 4,567 \\
5 & R1 & $-0,15$ & 4,893 \\
6 & R2 & $-0,16$ & 4,567 \\
7 & R3 & $-0,10$ & 5,402 \\
8 & R4 & $-0,12$ & 6,033 \\
9 & R5 & $-0,13$ & 5,028 \\
10 & RV1 & $-0,17$ & 4,893 \\
11 & RV2 & $-0,12$ & 4,893 \\
12 & RV3 & $-0,12$ & 4,893 \\
13 & RV4 & $-0,15$ & 5,402 \\
14 & A1 & $-0,15$ & 5,925 \\
15 & A2 & $-0,10$ & 5,787 \\
16 & A3 & $-0,10$ & 3,815 \\
17 & A4 & $-0,11$ & 7,865 \\
18 & E1 & $-0,14$ & 6,348 \\
19 & E2 & $-0,09$ & 7,492 \\
20 & E3 & $-0,12$ & 4,211 \\
21 & E4 & $-0,11$ & 4,893 \\
22 & E5 & $-0,11$ & 5,652 \\
\hline
\end{tabular}

Dari pengolahan data indeks PGCV, terdapat 5 prioritas perbaikan yang memiliki indeks paling tinggi. Oleh karena itu, layanan tersebut perlu mendapat perhatian untuk dilakukan perbaikan. Tabel 11 menunjukkan 5 prioritas variabel pelayanan untuk perbaikan berdasarkan hasil analisis IPGCV.

Tabel 11. Prioritas Perbaikan Berdasarkan IPGCV 


\section{KESIMPULAN}

Berdasarkan analisis yang telah dilakukan, maka hasil yang diperoleh adalah, bahwa gap antara persepsi dan harapan dari setiap dimensi kualitas pelayanan yaitu dimensi Tangible $-0,13$, dimensi Reliability -0,13, dimensi Responsive 0,14, dimensi Assurance -0,11 dan dimensi Emphaty -0,11. Gap terbesar terjadi pada dimensi responsive. Secara rata-rata, kualitas pelayanan masih perlu perbaikan karena gap antara persepsi dan harapan setiap dimensi adalah sebesar - 0,12.

Dari analisis tingkat kualitas pelayanan, dapat diketahui bahwa kualitas pelayanan perusahaan belum memenuhi harapan konsumen karena memiliki nilai kualitas kurang dari $1(Q<1)$ yaitu sebesar bernilai 0,84 . Berdasarkan hasil analisis IPGCV, maka dapat diketahui elemen-elemen yang perlu mendapatkan prioritas perbaikan kualitas pelayanan dari setiap dimensi kualitas. Secara berurutan, prioritas elemen tersebut yaitu dukungan terhadap karyawan dengan indeks 7,865 , tempat yang nyaman dan bersih dengan indeks 7,429, ketersediaan peralatan dengan teknologi terbaru dengan indeks 6/766, kemudahan akses profil perusahaan dengan indeks 6,348 dan ketepatan waktu pelayanan dengan indeks 6,033.

\section{DAFTARPUSTAKA}

[1] P. Puspitasari, S. K. Anggraeni, and N. Wahyuni, "Mengukur Indeks Kepuasan Masyarakat dan Menentukan Prioritas Perbaikan Melalui Potential Gain In Customer Value (Studi Kasus: Samsat Kota Cilegon)," J. Ind. Serv., vol. 1, no. 1, pp. 1-5, 2015.

[2] V. Charles, M. Kumar, and S. Suggu, "Adapting Fuzzy Linguistic Servqual Model: A comparative analysis of bank services," Middle-East J. Sci. Res., vol. 18, no. 8, pp. 1119-1132, 2013.

[3] B. Harto, "Analisis tingkat kepuasan pelanggan dengan pendekatan fuzzy servqual dalam upaya peningkatan kualitas pelayanan (studi kasus di bengkel resmi bajaj padang)," J. Teknolf, vol. 3, no. 1, pp. 20-30, 2015.

[4] N. Djamal and W. O. Widyarto, "Quality Services Measurement Using Fuzzy Service Quality (Fuzzy SERVQUAL) Method," Int. J. Eng. Res. Technol., vol. 6, no. 6, pp. 614-618, 2017.

[5] R. Perangin-Angin, E. S. M. Nababan, and F. Bu'ulolo, "Strategi Peningkatan Kualitas Pelayanan Kesehatan Menggunakan Integrasi Metode Fuzzy Servqual (Studi Kasus: RSU Vina Estetica Medan)," Saintia Mat., vol. 1, no. 6, pp. 529-541, 2013.

[6] A. Enny, "Peningkatan Kualitas Pelayanan Jasa Kesehatan Di Instalasi Rawat Inap Dengan Metode ServqualFuzzy (Studi Di Rumah Sakit Umum Daerah (RSUD) Jombang)," J. Penelit. IImu-IImu Tek., vol. 9, no. 1, pp. 58-69, 2009.

[7] H.-Y. Hu, Y.-C. Lee, and T.-M. Yen, "Service quality gaps analysis based on fuzzy linguistic SERVQUAL with a case study in hospital out-patient services," TQM J., vol. 22, no. 5, pp. 499-515, 2010.

[8] N. M. Stefano, N. Casarotto Filho, R. Barichello, and A. P. Sohn, "A fuzzy SERVQUAL based method for evaluated of service quality in the hotel industry," Procedia CIRP, vol. 30, pp. 433-438, 2015.

[9] F. Frieyadie and D. Alramuri, "Implementasi Metode Fuzzy Servqual untuk Menilai Pelayanan Customer Service terhadap Kepuasan Pelanggan di PT. Telkom," J. Techno Nusa Mandiri, vol. 14, no. 2, pp. 111-116, 2017.

[10] H. Rosyidah, T. Wuryandari, and A. Rusgiyono, "Analisis Kualitas Pelayanan Dengan Menggunakan Fuzzy Servqual, Kuadran IPA, Dan Indeks Pgcv," J. Gaussian, vol. 4, no. 4, pp. 885-894, 2015.

[11] S. F. Siregar, "Analisis Tingkat Kualitas Pelayanan dengan Metode Index Potential Gain Customer Value (PGCV) Di PT. Bank Muamalat Indonesia Cabang Medan," J. Sist. Tek. Ind., vol. 7, no. 4, pp. 40-47, 2006.

[12] R. Sukwadi, "Penentuan Prioritas Perbaikan Kualitas Layanan TransJakarta dengan Menggunakan Metode IPAPGCV," J. Rekayasa Sist. Ind., vol. 4, no. 2, pp. 64-69, 2015.

[13] A. Parasuraman, V. A. Zeithaml, and A. Malhotra, "ES-QUAL: A multiple-item scale for assessing electronic service quality," J. Serv. Res., vol. 7, no. 3, pp. 213-233, 2005.

[14] I. H. Chow, V. P. Lau, T. W. Lo, Z. Sha, and $\mathrm{H}$. Yun, "Service quality in restaurant operations in China: Decision-and experiential-oriented perspectives," Int. J. 
Hosp. Manag., vol. 26, no. 3, pp. 698710, 2007.

[15] M. M. Ulkhaq and M. P. B. Barus, "Analisis Kepuasan Pelanggan dengan Menggunakan SERVQUAL: Studi Kasus Layanan IndiHome PT. Telekomunikasi Indonesia, Tbk, Regional 1 Sumatera," J. Sist. dan Manaj. Ind., vol. 1, no. 2, pp. 6167, 2017.

[16] Z. Yamit, Manajemen Kualitas Produk dan Jasa. edisi pertama, cetakan kedua, Yogyakarta: Ekonisia, 2002.

[17] S. Kusumadewi and H. Purnomo, Aplikasi Logika Fuzzy untuk pendukung keputusan. Yogyakarta: Graha IImu, 2010.

[18] A. Parasuraman, V. A. Zeithaml, and L. L. Berry, "Servqual: A multiple-item scale for measuring consumer perc," J. Retail., vol. 64, no. 1, pp. 12-40, 1988.

[19] F. Sá, Á. Rocha, and M. P. Cota, "From the quality of traditional services to the quality of local e-Government online services: A literature review," Gov. Inf. Q., vol. 33, no. 1, pp. 149-160, 2016.

[20] L. Lee, M. J. Lee, and B. Dewald, "Measuring the customers' perception of tangible service quality in the restaurant industry: an emphasis on the upscale dining segment," J. Foodserv. Bus. Res., vol. 19, no. 1, pp. 21-38, 2016.

[21] D. W. Ariani, Pengendalian kualitas
Statistik (Pendekatan Kuantitatif dalam Manajemen Kualitas). Yogyakarta: Andi, 2004.

[22] B. Wicaksono, N. W. Setyanto, and O. Oktavianty, "Analisis Kepuasan Pelanggan Pada Pelayanan Kesehatan Dengan Menggunakan Metode Potential Gain in Customer Value (Pgcv) Dan Entropy (Studi Kasus: Rumah Sakit Mardi Waluyo Kota Blitar)," J. Rekayasa dan Manaj. Sist. Ind., vol. 2, no. 3, pp. p637647, 2014.

[23] H. Umar, Metode penelitian untuk skripsi dan tesis bisnis. Jakarta: PT RajaGrafindo Persada, 2008.

[24] S. P. Astuti, W. Wilasari, and D. E. Utami, "Meningkatkan Kualitas Pelayanan Di Bank Syariah Penelitian Dengan Fuzzy Servqual Dan Dimensi Carter," Int. Res. J. Bus. Stud., vol. 2, no. 1, pp. 47-58, 2012.

[25] N. N. Fajriyah, U. Effendi, and I. Santoso, "Analisis Kepuasan Pelanggan dengan Menggunakan Metode Fuzzy Servqual pada Restoran X di Kota Malang," TIP UB, 2014.

[26] X. Papadomichelaki and G. Mentzas, "A multiple-item scale for assessing $e$ government service quality," in International Conference on Electronic Government, 2009, pp. 163-175. 